\title{
LIBERDADE DE EXPRESSÃO E DISCURSO DO ÓDIO: O CONFLITO DISCURSIVO NAS REDES SOCIAIS
}

\author{
FREEDOM OF EXPRESSION AND HATE SPEECH: \\ THE DISCURSIVE CONFLICT IN SOCIAL NETWORKS
}

\begin{abstract}
TATIANA STROPPA
Possui graduação em Bacharelado em Ciências Jurídicas e Sociais - Instituição Toledo de Ensino (2002) e mestrado em Pós-graduação stricto sensu - Instituição Toledo de Ensino (2006). Atualmente é professora de Direito Constitucional e de Direito Processual Civil do Centro Universitário de Bauru (ITE-SP) e de Direito Constitucional das Faculdades Integradas de Jaú - Curso de Direito. Tem experiência na área de Direito, com ênfase em Direito Público, atuando principalmente nos temas que envolvem a liberdade de expressão e o direito de informação. tatianastroppa@hotmail.com
\end{abstract}

WALTER CLAudius RothenbuRg

Doutor em Direito do Estado (1998) e Mestre em Direito Público (1993) pela Universidade Federal do Paraná (1998). Pósgraduado em Direito Constitucional pela Universidade de Paris II (1992), Graduação em Direito pela Universidade Federal do Paraná (1988). Professor da Instituição Toledo de Ensino - ITE e convidado de diversas instituições de ensino. Autor dos livros "Direitos fundamentais" (2014), "Direito Constitucional" (2010), "Inconstitucionalidade por omissão e troca de sujeito" (2005), "Princípios Constitucionais" (1999) e "A pessoa jurídica criminosa" (1997). Autor de diversos capítulos e artigos. Procurador Regional da República em São Paulo. Atuação nas seguintes áreas: Direito Constitucional, Direitos Fundamentais, Controle de Constitucionalidade, Teoria Geral do Direito, Ministério Público, Povos e Comunidades Tradicionais, Meio Ambiente e Patrimônio Histórico, Direito Previdenciário. walter.claudius@terra.com.br

\section{RESUMO}

0 presente artigo pretende discutir os limites que precisam ser traçados para enfrentar o discurso do ódio intensificado pela utilização da internet e das redes sociais que reduzem, por um lado, a interação social direta entre os atores que passam a ser produtores de mensagens e não apenas receptores, e por outro, potencializam o anonimato e permitem a publicação instantânea de conteúdos. De forma a cumprir esse objetivo, emprega-se uma pesquisa bibliográfica complementada com dados jurisprudenciais brasileiros. Conclui-se que as restrições, que devem ser preservadas para casos extremos, ocorrerão pela ponderação dos interesses em jogo em conformidade com uma metódica de proporcionalidade, de modo a evitar decisões desproporcionais que interditem o debate público. Por fim, apresenta alguns parâmetros objetivos que devem ser seguidos pelo julgador que estiver diante de litígios envolvendo o conflito mencionado.

Palavras-chave: Discurso do ódio; Liberdade de expressão; Redes Sociais

\begin{abstract}
This article discusses the limitations that need to be drawn to face hate speech intensified by the use of the Internet and social networks that reduce, on one hand, direct social interaction among actors who become producers of messages and not just receptors, and on the other, enhance anonymity and allow oneself to instantly post content on line. In order to accomplish this goal, a literature search supplemented by Brazilian case law data is employed. It follows that restrictions, which must be preserved for extreme cases, occur by the balance of interests at stake in accordance with a methodical proportionality of so as to avoid disproportionate decisions that prevent public debate. Finally, it presents some objective parameters that must be followed by the judge that is before a case between the mentioned conflict.
\end{abstract}




\section{SUMÁRIO}

INTRODUÇAO; 1 A LIBERDADE DE EXPRESSÃO E A POSIÇÃO PREFERENCIAL; 1.1 A liberdade de expressão e o discurso de ódio; 2 PARÂMETROS PARA AS RESTRIÇÕES À LIBERDADE DE EXPRESSÃO DIANTE DE DISCURSOS DO ÓDIO NAS REDES SOCIAIS; CONCLUSÃO; REFERÊNCIAS.

\section{INTRODUÇÃO}

A proteção da liberdade de expressão está diretamente associada à garantia da dignidade da pessoa humana e da democracia. Ocorre que as relações sociais, o ambiente democrático e o contexto multicultural impõem contornos ao direito de expressão, que - tal como os demais direitos fundamentais - conhece restrições.

A presente abordagem ocupa-se da possibilidade de limitação à liberdade de expressão em razão da exteriorização de conteúdos discriminatórios ou discursos do ódio. Sob o manto enganoso da liberdade, a expressão discriminatória vulnera objetivos da República brasileira, de construção de uma sociedade livre, justa e solidária, compromissada com a promoção do bem de todos, sem preconceitos de origem, raça, sexo, cor, idade e quaisquer outras formas de discriminação (Constituição, art. $3^{\circ}$, I e IV).

O exercício abusivo da liberdade de expressão é potencializado com a generalização do acesso à internet que permite às pessoas assumir uma posição ativa na relação comunicacional ao saírem da posição de receptores da informação e passarem à posição de criadoras de conteúdos, os quais podem ser divulgados de maneira instantânea, sobretudo nas mídias sociais como Facebook, Twitter e Instagram, com acentuada velocidade de propagação e uma aparente possibilidade de anonimato.

Com isso, os discursos discriminatórios (hate speech) ganharam sua versão cibernética e, nesse contexto, a reflexão prática a respeito dos limites da liberdade de expressão em razão da veiculação de mensagens preconceituosas que atingem as pessoas e os grupos vulneráveis também precisa ser feita.

O trabalho está dividido em dois tópicos centrais, a saber: na primeira parte são analisados o direito de expressão, em um primeiro momento, e o discurso do ódio em sucessão. No segundo item são trazidos parâmetros que devem nortear as restrições à liberdade de 
expressão diante de discursos discriminatórios veiculados nos meios de comunicação, principalmente nas redes sociais ${ }^{1}$.

\section{A LIBERDADE DE EXPRESSÃO E A POSIÇÃO PREFERENCIAL}

A liberdade de expressão é assegurada em inúmeros tratados internacionais, entre eles, por exemplo, a Declaração Universal dos Direitos Humanos (ONU, 1948 - art. 19), a Convenção Americana sobre Direitos Humanos (OEA, 1969 - art. 13) e o Pacto Internacional sobre Direitos Civis e Políticos (ONU, 1966 - art. 19), dos quais o Brasil é signatário.

$\mathrm{Na}$ Constituição brasileira, o direito de expressão consta de diversos dispositivos, tanto no capítulo dos direitos e deveres individuais e coletivos (art. $5^{\circ}$, IV, V e IX), quanto no capítulo destinado à comunicação social em que houve o reconhecimento expresso de que "a criação, a expressão e a informação, sob qualquer forma, processo ou veículo não sofrerão qualquer restrição, observado o disposto nesta Constituição" (art. 220). Assentou-se ainda que "[é] vedada toda e qualquer censura de natureza política, ideológica e artística” (art. 220, § $2^{\circ}$ ). À perspectiva subjetiva do direito fundamental acresceu-se uma perspectiva objetiva, à medida que a afirmação do direito subjetivo conferido às pessoas para se manifestarem e interagir com os outros foram agregados princípios e regras que devem nortear o regime jurídico dos meios de comunicação a fim de que os cidadãos possam ser suficiente e adequadamente informados.

O reconhecimento constitucional do direito de expressão compreende a possibilidade de exteriorização de crenças, convicções, ideias, ideologias, opiniões, sentimentos e emoções, pelas mais diversificadas plataformas informativas hoje existentes. A proteção conferida pelo direito de expressão vai além do ato de poder pensar e alcança a possibilidade de divulgar o que se pensa, com o mais variado conteúdo, visto que as mensagens não podem ser restritas em razão das motivações políticas, econômicas ou filosóficas que thes sejam subjacentes, ou em

\footnotetext{
${ }^{1}$ Conforme Manuel Castells as redes podem ser definidas como "um conjunto de nós interconectados. Nó é o ponto no qual uma curva se entrecorta. Concretamente, o que um nó é depende do tipo de redes concretas de que falamos" [...] Redes são estruturas abertas capazes de expandir de forma ilimitada, integrando novos nós desde que consigam comunicar-se dentro da rede, ou seja, desde que compartilhem os mesmos códigos de comunicação [...]. (cf. CASTELLS, Manuel. A sociedade em rede. São Paulo: Paz e Terra, 2005. p. 566).
} 
função de sua suposta banalidade ou relevância, conforme defendem Canotilho, Machado e Gaio Júnior $^{2}$, o âmbito de proteção da liberdade de expressão é alargado.

$\mathrm{Na}$ verdade, em um ambiente democrático, ainda que não se deva afirmar a primazia absoluta e definitiva de algum direito fundamental, há aqueles que têm um destaque relativo, gozam de preferência inicial e cobram razões especialmente fortes para justificar-lhes a restrição. Tal é a situação da liberdade de expressão que, tanto em sua perspectiva individual, como na coletiva, serve de fundamento para o exercício de outros direitos fundamentais e para a própria democracia enquanto regime que requer a formação de uma opinião pública livre.

Esse entendimento de posição de preferência (preferred position) foi adotado pelo Tribunal Constitucional espanhol (STC $n^{\circ}$ 51/1989) ao conferir primazia ao direito de expressão na solução de conflito entre dois direitos, conforme assinala David Ortega Gutiérrez:

[...] la libre expresión y la no menos libre información se configuran en principio como derechos de la ciudadanía, aun cuando con talante instrumental de una función que garantiza la existencia de una opinión pública también libre, indispensable para la efectiva consecución del pluralismo político como valor esencial del sistema democrático ${ }^{3}$.

De fato, o relator Min. Carlos Ayres Britto ao considerar a antiga Lei de Imprensa (Lei n. 5.250 de 1967) inteiramente incompatível com a Constituição Federal de 1988 manifestou, em várias passagens de seu voto proferido no julgamento da ADPF $\mathrm{n}^{\circ} 130$, a "primazia das liberdades de manifestação do pensamento e de expressão em sentido genérico", dentre as quais é possível destacar a seguinte:

[...] Se cada autor, cada escritor, cada pensador e cada artista tem por quintessência do seu DNA imaterial a ironia, por hipótese, como impedir que seja igualmente irônica a sua produção intelectual, ou artística, ou comunicacional? E se ele for um incréu (Millôr Fernandes fala do direito fundamental à descrença), um agnóstico, um iconoclasta, um evolucionista, um questionador, um anarquista ("Anarquistas, Graças a Deus", é o mais conhecido dos livros de Zélia Gattai), um arauto do holismo, da utopia e do surreal, como impedir que venha a contraditar, incomodar, desagradar ou até mesmo ofender, chocar, vexar, revoltar quem não o seja? Como proibir que o indivíduo seja ele mesmo em tudo que fizer, de sorte a que tudo que ele fizer seja ele mesmo? ${ }^{4}$

\footnotetext{
${ }^{2}$ CANOTILHO, José Joaquim Gomes; MACHADO, Jónatas Eduardo Mendes; GAIO JÚNIOR, Antônio Pereira. Biografia não autorizada versus liberdade de expressão. Curitiba: Juruá, 2014, p. 29.

${ }^{3}$ GUTIÉRREZ, David Ortega. Manual de derecho de la información. Madri: Centro de Estudios Ramon Areces, 2003, p. 73.

${ }^{4}$ BRASIL. Supremo Tribunal Federal. ADPF 130/DF, Trecho do voto do rel. Min. CARLOS AYRES BRITTO, DJU de $30 / 04 / 2009$.
} 
Outra menção à posição preferencial conferida à liberdade de expressão foi feita pelo Min. Luís Roberto Barroso ao votar pela procedência da Ação Direta de Inconstitucionalidade (ADI) 4815 para declarar inexigível a autorização prévia para a publicação de biografias constante nos artigos 20 e 21 do Código Civil. 0 Ministro, ao destacar a tensão entre a liberdade de expressão e o direito à informação, de um lado, e os direitos da personalidade (privacidade, imagem e honra), do outro -, afirmou que a liberdade de expressão deve ser tratada como uma liberdade preferencial e para tanto mencionou três razões: $1^{\text {a }}$ ) por causa do histórico brasileiro de censura a jornais, revistas e obras artísticas, que perdurou até a última ditadura militar; $2^{\mathrm{a}}$ ) por ser a liberdade de expressão pressuposto para o exercício dos outros direitos fundamentais; $3^{\mathrm{a}}$ ) porque a liberdade de expressão é indispensável para o conhecimento da história, para o progresso social e para o aprendizado das novas gerações ${ }^{5}$.

Existe, assim, uma inclinação argumentativa em favor do direito de expressão (posição preferencial), ou seja, “existindo dúvida a respeito da legitimidade constitucional da restrição, é

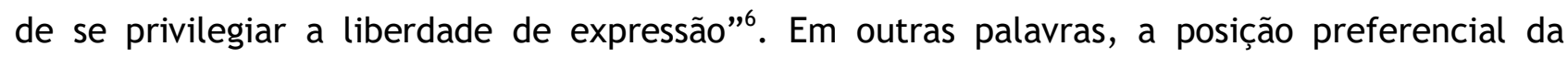
liberdade de expressão significa que, na ponderação entre os direitos envolvidos, esta recebe de início um peso maior, exigindo-se que a pessoa prejudicada por uma mensagem prove o dolo ou culpa grave para conseguir êxito em uma ação ajuizada contra o meio de comunicação ${ }^{7}$, ou seja, o ônus argumentativo para a restrição fica a cargo daquele que alega a violação.

Conforme as orientações supracitadas há uma opção, em regra, pela composição dos danos a posteriori por meio, por exemplo, do direito de resposta, da indenização a até mesmo, em último caso, da responsabilização penal, "salvo naqueles casos excepcionais de patente desproporcionalidade no ingresso dos direitos de personalidade"8.

É oportuno, neste passo, frisar que não se pode sustentar a prioridade absoluta da liberdade de expressão ou a possibilidade apenas de compensação posterior pelo abuso cometido. Afinal, os diversos direitos fundamentais convivem no ambiente normativo. A doutrina

\footnotetext{
${ }^{5}$ BRASIL. Supremo Tribunal Federal. ADI 4815, Trecho do voto do Min. Luís ROBERTO BARROSO, DJU de $10 / 06 / 2015$.

${ }^{6}$ SARLET, Ingo Wolfgang; MARINONI, Luiz Guilherme; MITIDIERO, Daniel. Curso de direito constitucional. 2. ed. São Paulo: Revista dos Tribunais, 2013, p. 470-471.

7 Cf. CHEQUER, Cláudio. Liberdade de expressão como direito fundamental preferencial "prima facie". Disponível em: <htt//:www.cartaforense.com.br/conteudo/artigos/liberdade-de-expressao-como-direitofundamental-preferencial-prima-facie/5776>. Acesso em: 24 jan.2013.

${ }^{8}$ STROPPA, Tatiana. As dimensões constitucionais do direito de informação e o exercício da liberdade de informação jornalística. Belo Horizonte: Fórum, 2010, p. 205.
} 
rechaça a perspectiva de hierarquia ou superioridade (prevalência absoluta) entre os direitos fundamentais, sendo consenso a inexistência de direito fundamental absoluto? .

A própria Constituição, ao tratar generosamente do direito de expressão, explicitou que não haverá restrições, mas que haverá de ser "observado o disposto nesta Constituição" (art. 220, caput), ou seja, só os demais direitos fundamentais e bens constitucionais servem como restrição. Ao dispor sobre a defesa do Estado e das instituições democráticas, a Constituição previu, em relação ao estado de sítio (art. 139, III), a possibilidade de "restrições[...] à prestação de informações e à liberdade de imprensa, radiodifusão e televisão, na forma da lei”.

É fora de dúvida que a posição de preferência dada à liberdade de expressão determina a excepcionalidade da proibição prévia de manifestações que ficará reservada para aqueles casos em que seja impossível a composição posterior do dano eventualmente causado aos direitos da personalidade daqueles que são atacados nas mensagens.

Com o desenvolvimento acima procurou-se esboçar os contornos gerais da liberdade de expressão para possibilitar o breve estudo acerca do discurso do ódio. Isso porque dentre os diversos conflitos que envolvem a liberdade de expressão situam-se as manifestações que expressam mensagens violentas, intolerantes e eivadas de conteúdo preconceituoso.

\subsection{A liberdade de expressão e o discurso do ódio}

Se o conflito de ideias e de posicionamentos é inevitável em uma sociedade plural a questão que se coloca com particular relevo consiste em saber se os conteúdos envolvendo o discurso do ódio (hate speech) também estão protegidos pelo âmbito normativo da liberdade de expressão. E mais: como controlar a discriminação preconceituosa num ambiente democrático, em que as pessoas e grupos devem ter o direito de manifestar-se, criticar e discordar?

O primeiro ponto consiste em definir o que é o discurso do ódio?

Segundo Rosane Leal da Silva et al, o “discurso de ódio” caracteriza-se pelo conteúdo segregacionista, fundado na dicotomia da superioridade do emissor e na inferioridade do

9 Cf. voto do Min. Luís Roberto Barroso no julgamento da ADI 4815. Disponível em: <http://www.stf.jus.br/arquivo/cms/noticiaNoticiaStf/anexo/ADI4815LRB.pdf>. 
atingido (a discriminação), e pela externalidade, ou seja, existirá apenas quando for dado a conhecer a outrem que não o próprio emissor ${ }^{10}$.

Salientando a discriminação preconceituosa Winfried Brugger (2007, p. 118) afirma que: “[...]o discurso do ódio refere-se a palavras que tendem a insultar, intimidar ou assediar pessoas em virtude de sua raça, cor, etnicidade, nacionalidade, sexo ou religião, ou que têm a capacidade de instigar violência, ódio ou discriminação contra tais pessoas"11.

Em outras palavras, o discurso do ódio consiste na divulgação de mensagens que difundem e estimulam o ódio racial, a xenofobia, a homofobia e outras formas de ataques baseados na intolerância e que confrontam os limites éticos de convivência com o objetivo de justificar a privação de direitos, a exclusão social e até a eliminação física daqueles que são discriminados.

A Constituição brasileira dispõe expressamente que "a lei punirá qualquer discriminação atentatória dos direitos e liberdades fundamentais" (art. $5^{\circ}, \mathrm{XLI}$ ) e, logo em seguida, que "a prática do racismo constitui crime inafiançável e imprescritível, sujeito à pena de reclusão, nos termos da lei" (art. 5 XLII). Já, o artigo 13, § $7^{\circ}$, da Convenção Americana de Direitos Humanos, da qual o Brasil é signatário, determina que "a lei deve proibir toda propaganda a favor da guerra, bem como toda apologia ao ódio nacional, racial ou religioso que constitua incitamento à discriminação, à hostilidade, ao crime ou à violência".

A Lei 12.288/2010, que instituiu o Estatuto da Igualdade Racial, estabelece, em seu artigo 26, que “o poder público adotará as medidas necessárias para o combate à intolerância com as religiões de matrizes africanas e à discriminação de seus seguidores, especialmente com o objetivo de: I - coibir a utilização dos meios de comunicação social para a difusão de proposições, imagens ou abordagens que exponham pessoa ou grupo ao ódio ou ao desprezo por motivos fundados na religiosidade de matrizes africanas".

No mesmo passo a Convenção Internacional pela Eliminação de todas as Formas de Discriminação Racial (2001) insta os Estados a incentivarem os meios de comunicação a evitarem os estereótipos baseados em racismo, discriminação racial, xenofobia e a intolerância correlata. E a Convenção Interamericana para Prevenir, Punir e Erradicar a Violência Contra a Mulher

\footnotetext{
${ }^{10}$ SILVA, Rosane Leal da et al . Discursos de ódio em redes sociais: jurisprudência brasileira. Rev. direito GV, São Paulo, v. 7, n. 2, Dec. 2011. p.445-468.

11 BRUGGER, Winfried. Proibição ou proteção do discurso do ódio? Algumas observações sobre o direito alemão e o americano. Trad. Maria Angela Jardim de Santa Cruz Oliveira. Revista de Direito Público, v. 15 n. 117, jan./mar. 2007.
} 
(1994) afirma que os Estados-partes concordam em "estimular os meios de comunicação a elaborar diretrizes adequadas de difusão que contribuam para a erradicação da violência contra a mulher em todas as suas formas e a realçar o respeito à dignidade da mulher”.

O Artigo 20 do Pacto Internacional sobre Direitos Civis e Políticos determina que: “1. Será proibido por lei qualquer propaganda em favor de guerra. 2. Será proibida por lei qualquer apologia do ódio nacional, radical, racial ou religioso que constitua incitamento à discriminação, à hostilidade ou à violência."

Baseado nesse dispositivo, a Artigo 19, em estudo que envolveu um grupo de oficiais da ONU e de outras organizações, reunidos em encontros realizados em Londres nos dias 11 de dezembro de 2008 e 23-24 de fevereiro de 2009, elaborou os denominados "Princípios de Camden sobre a Liberdade de Expressão e Igualdade", sendo que o $12^{\circ}$ princípio é destinado a oferecer uma proposta para que os Estados possam elaborar um texto legal acerca do discurso do ódio:

Princípio 12: Incitação ao ódio.

12.1. Todos os Estados devem adotar legislação que proíba qualquer promoção de ódio religioso, racial ou nacional que constitua uma incitação à discriminação, hostilidade ou violência (discurso do ódio). Sistemas jurídicos nacionais devem deixar claro, seja de forma explícita ou por meio de interpretação impositiva, que:

i. Os termos 'ódio' e 'hostilidade' se referem a emoções intensas e irracionais de opróbrio, animosidade e aversão ao grupo visado.

ii. O termo 'promoção' deve ser entendido como a existência de intenção de promover publicamente o ódio ao grupo visado.

iii. O termo 'incitação' se refere a declarações sobre grupos religiosos, raciais ou nacionais que criam risco iminente de discriminação, hostilidade ou violência a pessoas pertencentes a esses grupos.

iv. A promoção, por parte de comunidades diferentes, de um sentido positivo de identidade de grupo não constitui discurso do ódio. ${ }^{12}$

Esses princípios são importantes porque a divergência de opiniões é inevitável em sociedades pluralistas. Junte-se isso ao fato de que no Brasil o sistema de informação foi construído de forma totalmente assimétrica entre os sistemas privado, público e estatal e inúmeros grupos ficaram alijados da esfera comunicativa. Agora, com as redes sociais, conseguem um canal para escoarem os seus conteúdos contribuindo para aumentar o dissenso. Estas permitiram que os discursos do ódio que já existiam ganhassem visibilidade e atingissem muito mais pessoas e de uma maneira difícil de ser controlada.

\footnotetext{
12 Artigo 19. Princípios de Camden sobre a Liberdade de Expressão e Igualdade. Disponível em: < http: / / www. refworld.org/cgi-in/texis/vtx/rwmain/opendocpdf. pdf?reldoc=y\&docid=4b5827292>. Acesso em: 02 mar.2015.
} 
Ainda, é preciso superar a percepção de que a liberdade de expressão é apenas uma liberdade negativa, ou seja, que existe liberdade apenas quando não há uma interferência externa, identificada, sobretudo, com atuação do Estado, que impeça o sujeito de fazer o que quiser. Há que compreender que o Estado, ao contrário de ser inimigo da liberdade de expressão, pode exercer um papel positivo ${ }^{13}$ para aqueles grupos que, sem a garantia do Estado, não conseguem se expressar no espaço público porque há um "efeito silenciador" 14 promovido pelo discurso dos grupos dominantes.

Se o consenso é praticamente impossível de ser atingido em sociedades multiculturais, a coexistência pacífica é um valor que deve nortear a vida cotidiana. Se o direito de expressão é restringível diante de discursos discriminatórios, importa muito traçar parâmetros que norteiem o aplicador do Direito.

\section{PARÂMETROS PARA AS RESTRIÇÕES À LIBERDADE DE EXPRESSÃO DIANTE DE DISCURSOS DO ÓDIO NAS REDES SOCIAIS}

Como já defendido, entende-se que não existe uma hierarquia predefinida de direitos fundamentais, nenhum deles é absoluto e todos convivem em concordância prática, ou seja, nas situações de tensão e conflito concreto, os direitos fundamentais em jogo devem ser manejados com o melhor rendimento em relação ao menor sacrifício possível, numa lógica de proporcionalidade ${ }^{15}$.

Portanto, o direito de expressão não goza de uma preferência incondicionada, sendo suscetível de restrição em razão da concorrência negativa de outros direitos fundamentais e bens constitucionais, como ocorre quando há divulgação de discursos discriminatórios. 0 intérprete que se vê desafiado por um problema que afeta a liberdade de expressão não consegue poupar esforços na aplicação concreta do direito, pois não existe autorização jurídica para afastar o trabalho delicado de concordância prática dos direitos envolvidos.

\footnotetext{
${ }^{13}$ STROPPA, Tatiana. As dimensões constitucionais do direito de informação e o exercício da liberdade de informação jornalística. Belo Horizonte: Fórum, 2010. p. 138-142.

${ }^{14}$ FISS, Owen M. A ironia da liberdade de expressão: Estado, regulação e diversidade na esfera pública. Rio de Janeiro: Renovar, 2005. p. 30.

15 ROTHENBURG, Walter Claudius. Direitos fundamentais. São Paulo: Método, 2014. P. 28-29; ROTHENBURG, Walter Claudius. Princípio da proporcionalidade. In: OLIVEIRA Neto, Olavo de; LOPES, Maria Elizabeth de Castro (Org.). Princípios processuais civis na Constituição. Rio de Janeiro: Elsevier, 2008, p. 283-319.
} 
Cada vez mais as redes sociais concentram conteúdos contendo discursos do ódio voltados deliberadamente a incitar a discriminação e o tratamento degradante a determinados grupos socais com conteúdos racistas, homofóbicos, xenofóbicos e intolerantes com determinadas religiões e com pessoas com deficiência.

Diante da necessidade de fixação de parâmetros para enquadrar um discurso como sendo do ódio, a Artigo 19, tendo como norte os "Princípios de Camden sobre a Liberdade de Expressão e Igualdade" supracitados, recomenda a verificação dos seguintes critérios:

i. severidade: a ofensa deve ser "a mais severa e profunda forma de opróbrio".
ii. intenção: deve haver a intenção de incitar o ódio.
iii. conteúdo ou forma do discurso: devem ser consideradas a forma, estilo e
natureza dos argumentos empregados.
iv. extensão do discurso: o discurso deve ser dirigido ao público em geral ou à um
número de indivíduos em um espaço público.
v. probabilidade de ocorrência de dano: o crime de incitação não necessita que o
dano ocorra de fato, entretanto é necessária a averiguação de algum nível de
risco de que algum dano resulte de tal incitação.
vi. iminência: o tempo entre o discurso e a ação (discriminação, hostilidade ou
violência) não pode ser demasiado longo de forma que não seja razoável imputar
ao emissor do discurso a responsabilidade pelo eventual resultado.
v. contexto: o contexto em que é proferido o discurso é de suma importância
para verificar se as declarações tem potencial de incitar ódio e gerar alguma
ação ${ }^{16}$.

No fundamento desses critérios está a premissa de que as expressões de ódio não contribuem para o debate e precisam ser reprimidas, mas que isso não pode acarretar a supressão de discursos moralmente reprováveis ou dissonantes porque tal comportamento comprometeria o cerne da liberdade de expressão. Portanto, não é legítima a restrição a manifestações pelo simples fato de rejeitarem opiniões majoritárias ou divergirem dos posicionamentos oficiais adotados pelo governo.

Relevante salientar que os parâmetros que justificarão as restrições devem estar muito bem fundamentados, haja vista uma evidência histórica: as limitações à liberdade de expressão revelam-se muito mais nocivas para a humanidade do que aptas à criação de uma sociedade mais justa e solidária.

Quanto às vítimas, aponta Daniel Sarmento ${ }^{17}$ que importa considerar “[o] grau de dor psíquica, angústia, medo ou vergonha que as manifestações de ódio, intolerância e desprezo motivadas por preconceito possam provocar nos seus alvos".

${ }^{16}$ Disponível em:< http://artigo19.org/centro/files/discurso_odio.pdf>. Acesso em: 02 març. 2015. 
No Brasil, a Lei $n^{\circ} 7.716 / 1989$ (com as alterações promovidas pela Lei $n^{\circ}$ 12.735/2012 e pela Lei $n^{\circ}$ 12.288/2010) prevê como crime a prática de discriminação por critério de raça, cor, etnia, religião ou procedência nacional, permitindo que o juiz determine a cessação das transmissões radiofônicas, televisivas, eletrônicas ou da publicação por qualquer meio, bem como a interdição das respectivas mensagens ou páginas de informação na rede mundial de computadores $^{18}$ (art. 20, § $3^{\circ}$, II e III).

Em relação à forma de divulgação, a Lei $n^{\circ} 7.716$ determina aumento de pena a quem pratica, induz ou incita tal discriminação ou preconceito utilizando-se dos meios de comunicação social ou publicação de qualquer natureza (art. 20, $\S 2^{\circ}$ ).

Nas diversas manifestações de pensamento, é relevante observar se a mensagem é particularizada a um indivíduo ou se é uma opinião generalizada em relação a todo um grupo. A discriminação contra um grupo em geral não deve ficar desprotegida, afinal - como assevera Kwame Anthony Appiah- "a honra está associada intimamente e de muitas maneiras àqueles aspectos da identidade que derivam do pertencimento a grupos sociais" ${ }^{19}$.

Nas hipóteses em que as vítimas do discurso do ódio forem pessoas ou grupos vulneráveis, ignorados ou oprimidos pelos grupos hegemônicos as restrições ao direito de expressão de conteúdo discriminatório são mais aceitáveis, seja porque essa mensagem tende a reproduzir e talvez recrudescer a discriminação, seja porque provavelmente não haverá condições adequadas de contrapor ideias, opiniões e sentimentos compartilhados pela maioria ou pelos grupos hegemônicos, pois o acesso às novas tecnologias passa pela superação das barreiras socioeconômicas.

Daniel Sarmento propõe com acuidade "a adoção do princípio de que o Estado deve ser, a priori, mais tolerante diante dos excessos expressivos cometidos por membros de grupos estigmatizados contra a maioria, do que em relação aos perpetrados por integrantes da maioria

\footnotetext{
17 SARMENTO, Daniel. Livres e iguais. Estudos de Direito Constitucional. Rio de Janeiro: Lumen Juris, 2006. p. 261 e 277.

${ }^{18} \mathrm{O}$ governo federal, por meio da Portaria Interministerial $\mathrm{n}^{\circ} 2$, de 20 de novembro de 2014, institui Grupo de Trabalho, composto por membros das secretarias de Direitos Humanos, de Políticas para as Mulheres e de Igualdade Racial, além de OAB e Procuradoria Geral da República, e com parceria com a Universidade Federal do Espírito Santo, com a finalidade de adotar medidas visando receber denúncias de crimes de discriminação nas redes sociais on line. (OBSERVATÓRIO DA PRIVACIDADE E VIGILÂNCIA. Monitoramento em massa para combater crimes de ódio gera polêmica, 2015).

19 APPIAH, Kwame Anthony. O código de honra: como ocorrem as revoluções morais. São Paulo: Companhia das Letras, 2012. p. 74-75.
} 
contra estes grupos"20. Mais além, Jónatas E. M. Machado (2002, p. 189) aponta a necessidade de o Estado interferir positivamente para amplificar a voz dos grupos que estão excluídos do plano comunicativo ${ }^{21}$.

A provável intenção de quem se expressa, conquanto muitas vezes de difícil percepção ou comprovação, é outro aspecto relevante ${ }^{22}$. Assim, uma mensagem cujo objetivo é estimular deliberadamente a discriminação e, sobretudo, incitar a violência, enseja limites mais estreitos à liberdade de expressão.

Quanto ao teor e à proposta da mensagem, se o que existe é principalmente uma opinião (juízo de valor), mais forte deve ser a proteção ao direito de expressão. A opinião, que é prevalentemente subjetiva, deve ser considerada como socialmente menos idônea a atingir a percepção social que se tem da vítima do preconceito, pois o público em geral sabe ou pode saber que se trata apenas de uma opinião, por mais enfática e distorcida que seja. Por outro lado, se a mensagem é veiculada como notícia o seu impacto na percepção social é mais incisivo e pode justificar a restrição.

Considerando justamente o caráter noticioso da página jornalística "Portal Apuí", mantida na rede social Facebook, o Ministério Público Federal ajuizou Ação Civil Pública em face do administrador da página e conseguiu decisão liminar determinando a remoção da veiculação de publicações de cunho ofensivo e discriminatório direcionada aos indígenas da etnia Kagwahiva Tenharim ${ }^{23}$.

Já quanto a fatos relevantes efetivamente acontecidos, inclusive quanto à negação de eventos históricos, a proteção do direito de expressão é mais fraca. Sobretudo quando o evento histórico que é negado está vinculado à identidade da pessoa ou grupo ou representa uma forma particularmente intensa de discriminação, sendo esse o caso do holocausto judeu na Segunda Grande Guerra do século XX. A proibição de manifestações nazistas fundamenta-se, em parte, na evocação à violência praticada por esse regime totalitário e na intenção fortemente discriminatória que anima tal ideologia. A sociedade em geral deve desaprovar negações desse jaez, não apenas por serem manifestações de discriminações qualificadas, mas porque o

\footnotetext{
${ }^{20}$ SARMENTO, Daniel. Livres e iguais. Estudos de Direito Constitucional. Rio de Janeiro: Lumen Juris, 2006. p. 249.

${ }^{21}$ MACHADO, Jónatas Eduardo Mendes. Liberdade de expressão: dimensões constitucionais da esfera pública no sistema social. Coimbra: Coimbra, 2002. p. 189.

${ }_{22}$ Neste sentido: RIOS, Roger Raupp. Direito da antidiscriminação: discriminação direta, indireta e ações afirmativas. Porto Alegre: Livraria do Advogado, 2008. p. 102-112.

${ }^{23}$ BRASIL. Tribunal Regional Federal da $1^{\mathrm{a}}$ Região. Decisão interlocutória. Ação Civil Pública $n^{\circ} 0002206-$ 34.2014.4.01.3200. Juiz federal substituto Érico Rodrigo Freitas Pinheiro. DJ 14/02/2014.
} 
combate a elas representa um marco na luta contra a violação dos direitos fundamentais e da democracia.

A famosa decisão do Supremo Tribunal Federal brasileiro no caso Elwanger (autor e editor de publicação racista que negava o holocausto judeu e foi punido) ${ }^{24}$ justifica-se não apenas porque discute a realidade de um fato histórico, mas porque representa um posicionamento contrário às manifestações de negação com propósito fortemente discriminatório.

Manifestações artísticas apresentam-se como uma forma de expressão qualificada em que a liberdade é mais extensa e intensa. As manifestações artísticas traduzem expressões fortemente emocionais e também as diversas possibilidades de interpretação que a arte enseja. Ora, é preciso reconhecer às manifestações artísticas uma especial tolerância consolidada em resultados dissidentes, plurais e que repudiam a hegemonia de uma cultura única.

Se assim não for haverá decisões baseadas num juízo de definição do "politicamente correto" ${ }^{25}$ que afetarão negativamente as manifestações culturais e a liberdade de expressão.

Músicas inserem-se nesse contexto de maior liberdade, pois são exteriorizações artísticas e de crítica. Apesar disso, as músicas executadas pelas bandas White Power vem sendo questionadas porque defendem a supremacia racial branca, a secessão e a conspiração judaica, conforme esclarece Tailine Fátiva $\mathrm{Hijaz}^{26}$. Assim, por exemplo, ao procurar a música Peste Negra, da banda paulista Brigada NS, que estava no youtube ${ }^{27}$, observa-se que ela foi removida por violar "a política do Youtube que proíbe incitação ao ódio".

0 direito de expressão religiosa, filosófica e ideológica, consagrado claramente na Constituição brasileira (art. $5^{\circ}$, VI e VIII), é outro domínio em que os limites são estritos. Compreende-se que, no âmbito confessional, as mensagens podem ser sectárias e opostas a

\footnotetext{
${ }^{24}$ BRASIL. Supremo Tribunal Federal. HC 82.424/RS, rel. Min. MAURícIO CORRÊA, DJU de 19/03/2004.

${ }^{25}$ Observe-se, por exemplo, a situação que envolveu a escola de samba Unidos do Viradouro, em 2008, quando apresentou o samba-enredo "É de arrepiar". Referida escola foi proibida, por decisão judicial, de apresentar um carro alegórico com esculturas representando cadáveres nus empilhados e sapatos e trazendo um dos membros da escola vestido de Adolf Hitler sobre os corpos. Revelando, a nosso ver, uma restrição indesejada no âmbito da liberdade de expressão. (ARTIGO 19. Panorama sobre discurso de ódio no Brasil, n.d.). No mesmo sentido, conferir: Mandado de Segurança $n^{\circ} 30952$, STF, min. rel. Luiz Fux, impetrado pelo Instituto de Advocacia Racial e Ambiental (lara) contrário à adoção do livro infantil "Caçadas de Pedrinho", de Monteiro Lobato, sob o argumento de que o livro faz referências ao negro com "estereótipos fortemente carregados de elementos racistas". O Min. Luiz Fux, em 19 de dezembro de 2014, reconheceu a incompetência do STF e negou seguimento ao referido Mandado de Segurança.

${ }^{26}$ HIJAZ, Tailine Fátima. O discurso do ódio racial como limitação à liberdade de expressão no Brasil: o caso das bandas White Power. Revista Brasileira de Direito, n. 10, 2014, p. 15-32.

${ }^{27}$ Disponível em: <http://www.youtube.com/watch?v=rTOjjSxugGk\&bpctr=1351960896>. Acesso em: 17 marc. 2015.
} 
outras concepções, visto que, usualmente, radicam na aceitação de verdades transcendentes. Por isso, expressões discriminatórias são toleradas em maior grau no campo das religiões. Contudo, também elas não estão de antemão redimidas do "pecado" jurídico do abuso e podem ser restringidas, especialmente aquelas que visem deliberada e gratuitamente "demonizar" outras confissões.

Neste sentido, o Ministério Público Federal ajuizou uma Ação Civil Pública contra o Google, tendo como base uma representação feita pela Associação Nacional de Mídia Afro, solicitando a retirada de vídeos hospedados no YouTube com mensagens de intolerância contra religiões afro-brasileiras. Em decisão de 28/08/2014, a Sétima Turma Especializada do Tribunal Regional Federal da $2^{\mathrm{a}}$ Região deu provimento ao agravo de instrumento para determinar a imediata retirada dos vídeos listados pelo MPF da rede mundial de computadores, reconhecendo que "a cada dia em que os vídeos permanecem disponíveis no site youtube perpetuam-se as mensagens de ódio, discriminação, intolerância e violência neles contidas, que continuam sendo disseminadas a um número indeterminado de pessoas, tendo em vista o acesso irrestrito a tal conteúdo"28.

Registre-se ainda que apesar de o Marco Civil da Internet no Brasil (Lei 12.965/2014) não ter tratado da responsabilidade dos provedores de aplicação no caso de divulgação, por terceiros, de mensagens preconceituosas e discriminatórias a análise do Art. 19 indica que foi dada à liberdade de expressão uma preferência em relação a outros direitos que constumeiramente com ela colidem. Ainda, fixa que as restrições à liberdade de expressão e a responsabilização dos provedores de aplicação serão determinadas por decisão judicial.

Em suma, os episódios narrados revelam o conflito entre o direito de expressão e outros direitos fundamentais (ligados à imagem, à honra, ao sentimento religioso e de igualdade racial e sexual) de pessoas e grupos vulneráveis nas hipóteses em que a liberdade de expressão é utilizada para disseminar mensagens de discriminação e de opressão.

Como norte orientador da solução de conflitos, a convicção de que o combate às mensagens preconceituosas e discriminatórias deve passar em primeiro lugar pela construção de políticas públicas que assegurem a todos os grupos, principalmente aqueles que padecem de uma discriminação histórica, o acesso aos meios de comunicação para fazerem ecoar as suas ideias e convicções na esfera de discussão pública.

${ }^{28}$ BRASIL. Tribunal Regional Federal da $2^{\mathrm{a}}$ Região. Acórdão de decisão que deu provimento parcial ao Agravo de Instrumento. Agravo de Instrumento 201400001010430. Rel. Reis Friede. DJ: 28/08/2014. 
A conclusão a que se chega, portanto, é a de que os discursos do ódio não estão abrangidos pelo âmbito de proteção da liberdade de expressão, reiterando-se o cuidado que deve ser tomado para qualificar uma mensagem como sendo odiosa.

\section{CONCLUSÃO}

A consagração da liberdade de expressão alcança a possibilidade de divulgar o que se pensa, com o mais variado conteúdo, visto que as mensagens não podem ser restritas em razão das motivações políticas, econômicas ou filosóficas que thes sejam subjacentes, ou em função de sua suposta banalidade ou relevância. Tanto em sua perspectiva subjetiva, como, sobretudo, na objetiva, entende-se que a liberdade de expressão serve de fundamento para o exercício de outros direitos fundamentais e para o fortalecimento da democracia, o que justifica sua posição de preferência inicial em relação aos outros direitos que com ela colidem.

A posição preferencial atribuída à liberdade de expressão significa que, na ponderação entre os direitos envolvidos, esta recebe de início um peso maior, exigindo-se da pessoa prejudicada pela mensagem o ônus argumentativo para que haja restrição. Não significa posição de superioridade hierárquica em relação aos demais direitos fundamentais. Mas transfere para quem alega o abalo ou a afronta o ônus de provar a legitimidade da restrição.

A composição dos danos a outros direitos ocorrerá, em regra, a posteriori por meio, por exemplo, do direito de resposta, da indenização a até mesmo, em último caso, da responsabilização penal, salvo naqueles casos excepcionais de patente desproporcionalidade no ingresso dos direitos de personalidade.

O âmbito de proteção da liberdade de expressão não abarca o denominado discurso do ódio que consiste na divulgação de mensagens que difundem e estimulam o ódio racial, a xenofobia, a homofobia e outras formas de ataques baseados na intolerância e que confrontam os limites éticos de convivência com o objetivo de justificar a privação de direitos, a exclusão social e até a eliminação física daqueles que são discriminados.

Desta forma, nenhum espaço, seja o das manifestações artísticas, seja o da ironia, seja o da religião (ou convicção filosófica ou ideológica), seja o da política, é absolutamente protegido de limites e precisa reconhecer restrições necessárias para respeitar outros direitos e valores constitucionalmente protegidos. Como as redes sociais são espaços de comunicação os 
atos de comunicação nelas exteriorizados e voltados para a incitação à inferiorização de uma pessoa ou grupo com base em suas características como, por exemplo, etnia, orientação sexual, procedência regional ou nacional deverão sofrer limitações por se distanciarem do ideal de conformação de um sistema plural, democrático e com integração social.

Todavia, o peso que recai a favor da liberdade de expressão exige a análise e a ponderação criteriosa de diversos aspectos para que haja, no caso concreto, o enquadramento de um discurso como sendo de ódio. Os direitos fundamentais em jogo devem ser manejados com o melhor rendimento em relação ao menor sacrifício possível, numa lógica de proporcionalidade.

A começar, obviamente, pela severidade da ofensa e pelo grau de generalidade das imputações, mas a levar em conta também o autor (por exemplo, se ele fala a partir de uma posição de destaque social, como um agente político, servidor público ou artista), o contexto (por exemplo, uma entrevista, uma palestra ou uma música), a situação da vítima (por exemplo, sua vulnerabilidade social ou se ela é afetada individualmente ou enquanto membro de determinado grupo), a forma de divulgação (por exemplo, uma charge, uma opinião ou uma notícia inseridas em um blog ou rede social) e a probabilidade de que o discurso possa, de fato, ensejar o ódio e suscitar algum nível de risco de que algum dano resulte de tal incitação.

A valoração e a proscrição de mensagens sob a argumentação de que seja discurso de ódio não pode ser banalizada e alargada sob o jugo “do politicamente correto” e, assim, somente as manifestações explícitas e que tenham aptidão para ocasionar atitudes e práticas discriminatórias estão fora do âmbito de proteção da liberdade de expressão. A interdição do debate nestes casos, na prática, precisa vir acompanhada da construção de políticas públicas voltadas à inclusão das vozes historicamente excluídas e soterradas na esfera pública de discussão para que consigam sair da resignação, descortinar e enfrentar o desrespeito e o preconceito de maneira a valorizar a saudável diversidade que forma a sociedade brasileira.

\section{REFERÊNCIAS}

APPIAH, Kwame Anthony. 0 código de honra: como ocorrem as revoluções morais. São Paulo: Companhia das Letras, 2012.

ARTIGO 19. Princípios de Camden sobre Liberdade de Expressão e lgualdade. Londres: Artigo 19, 2009. Disponível em:< http://www.refworld.org/cgi-

bin/texis/vtx/rwmain/opendocpdf.pdf?reldoc=y\&docid=4b5827292>. Acesso em: 16 fev. 2015. 
ARTIGO 19. Panorama sobre discurso de ódio no Brasil. São Paulo, Artigo 19, n.d. Disponível em: <http://artigo19.org/centro/files/discurso_odio.pdf>. Acesso em 16 fev. 2015.

BRASIL. Lei $n^{\circ} 12.965$ de 23 abril de 2014. Estabelece princípios, garantias, direitos e deveres para o uso da Internet no Brasil. In: Diário Oficial da República Federativa do Brasil, Brasília, DF, 23 abr. 2014. Disponível em:< http://www.planalto.gov.br/ccivil_03/_ato2011-

2014/2014/lei/l12965.htm> Acesso em: 05 jul. 2014.

BRASIL. Lei n. 7.716, de 5 jan. 1989. Define os crimes resultantes de preconceito de raça ou de cor. In: Diário Oficial da República Federativa do Brasil, Brasília, DF, 5 jan. 1989. Disponível em:<http://www.planalto.gov.br/ccivil/Leis/L7716.htm>. Acesso em: 01 jul. 2014.

BRASIL. Supremo Tribunal Federal. Ação direta de inconstitucionalidade (ADI) 4815. Julgada procedente por unanimidade. Declaração de inexigibilidade da autorização prévia para a publicação de biografias. Trecho do voto do Min. LUís ROBERTO BARROSO, DJU de 10/06/2015. Disponível em: <http://www.stf.jus.br/arquivo/cms/noticiaNoticiaStf/anexo/ADI4815LRB.pdf>. Acesso em: 04 nov.2015.

BRASIL. Supremo Tribunal Federal. Decisão monocrática que negou seguimento ao Mandado de Segurança. Mandado de Segurança $n^{\circ}$ 30952. Rel.: Min. Luiz Fux. DJ: 19/12/2014. DOU 02/02/2015. Disponível em:

<http://www.stf.jus.br/portal/processo/verProcessoAndamento. asp?incidente=4165433>. Acesso em: 17 mar. 2015.

BRASIL. Supremo Tribunal Federal. Arguição de Descumprimento de preceito fundamental (ADPF) 130. Julgada procedente. Não recepção em bloco da Lei 5250/67. Voto do Relator: Min. Carlos Ayres Britto. Data do julgamento: 30 de abr.de 2009. Disponível em:< http:// www.stf.jus.br/arquivo/cms/noticiaNoticiaStf/anexo/adpf130.pdf>. Acesso em: 04 nov. 2015.

BRASIL. Supremo Tribunal Federal. Habeas corpus. Publicação de livros: antissemitismo. Racismo. Crime imprescritível. Conceituação. Abrangência constitucional. Liberdade de expressão. Limites. Ordem denegada. Habeas corpus 82.424-2. Rel.: Min. Moreira Alves. Data do julgamento: 17/09/2003. DOU 19/03/2004. Disponível em:

<http://redir.stf.jus.br/paginadorpub/paginador.jsp?docTP=AC\&docID=79052>. Acesso em: 04 jul. 2014.

BRASIL. Tribunal Regional Federal da $1^{a}$ Região. Decisão interlocutória. Ação Civil Pública ${ }^{\circ}$ 0002206-34.2014.4.01.3200. Ministério Público Federal e Ivani Valentim da Silva. Juiz federal substituto Érico Rodrigo Freitas Pinheiro. Seção Judiciária do Estado do Amazonas, DJ: 14 de fevereiro de 2014. Disponível em:

<http://www.pram.mpf.mp.br/news/2014/Liminar\%20Portal\%20Apui.pdf > Acesso em:17 de mar. de 2015.

BRASIL. Tribunal Regional Federal da $2^{a}$ Região. Acórdão de decisão que deu provimento parcial ao Agravo de Instrumento. Agravo de Instrumento 201400001010430. Rel. Reis Friede. DJ: 28/08/2014. DOU 16/09/2014. Disponível

em:<http://jurisprudencia.trf2.jus.br/v1/search?q=cache:ylqisGVvtlYJ:www.trf2.com.br/idx/trf 2/ementas/\%3Fprocesso\%3D201400001010430\%26CodDoc\%3D293472+retirada+dos+v\%C3\%ADdeos+ 
listados+pelo+MPF+da+rede+mundial+de+computadores+\&client=jurisprudencia\&output=xml_no_ dtd\&proxystylesheet=jurisprudencia\&tr=lang_pt\&ie=UTF-8\&site=ementas\&access=p\&oe=UTF $-8>$. Acesso em: 17 de mar. de 2015.

BRUGGER, Winfried. Proibição ou proteção do discurso do ódio? Algumas observações sobre o direito alemão e o americano. Trad. Maria Angela Jardim de Santa Cruz Oliveira. Revista de Direito Público, v. 15 n. 117, jan./mar. 2007. Disponível em:

<http://www.direitopublico.idp.edu.br/index.php/direitopublico/article/view/521/919>. Acesso em: 03 jul.2014.

CANOTILHO, José Joaquim Gomes; MACHADO, Jónatas Eduardo Mendes; GAIO JÚNIOR, Antônio Pereira. Biografia não autorizada versus liberdade de expressão. Curitiba: Juruá, 2014.

CASTELLS, Manuel. A sociedade em rede. volume I; 8 edição revista e ampliada; tradução de Roneide Vanancio Majer com colaboração de Klauss Brandini Gerhardt. São Paulo: Paz e Terra, 2005.

CHEQUER, Cláudio. Liberdade de expressão como direito fundamental preferencial "prima facie". Disponível em:< www.cartaforense.com.br/conteudo/artigos/liberdade-de-expressaocomo-direito-fundamental-preferencial-prima-facie/5776>. Acesso em: 24 jan.2013.

FISS, Owen M. A ironia da liberdade de expressão: Estado, regulação e diversidade na esfera pública. Rio de Janeiro: Renovar, 2005.

GUTIÉRREZ, David Ortega. Manual de derecho de la información. Madri: Centro de Estudios Ramon Areces, 2003.

HIJAZ, Tailine Fátima. O discurso do ódio racial como limitação à liberdade de expressão no Brasil: o caso das bandas White Power. Revista Brasileira de Direito, n. 10, 2014, p. 15-32. Disponível em: < http://file:///C:/Users/User/Downloads/599-2686-1-PB.pdf>. Acesso em: 10 mar. 2015.

MACHADO, Jónatas Eduardo Mendes. Liberdade de expressão: dimensões constitucionais da esfera pública no sistema social. Coimbra: Coimbra, 2002.

NOWAK, John E.; ROTUNDA, Ronald D. Constitutional law. 7. ed. St. Paul: West Publishing Co., 2004.

OBSERVATÓRIO DA PRIVACIDADE E VIGILÂNCIA. Monitoramento em massa para combater crimes de ódio gera polêmica. Disponível em: <http://www.cartacapital.com.br/sociedade/monitoramento-emmassa-para-combater-crimes-de-odio-gera-polemica-1118.html>. Acesso em 12 mar. 2015.

RIOS, Roger Raupp. Direito da antidiscriminação: discriminação direta, indireta e ações afirmativas. Porto Alegre: Livraria do Advogado, 2008.

ROTHENBURG, Walter Claudius. Direitos fundamentais. São Paulo: Método, 2014.

ROTHENBURG, Walter Claudius. Princípio da proporcionalidade. In: OLIVEIRA Neto, Olavo de; LOPES, Maria Elizabeth de Castro (Org.). Princípios processuais civis na Constituição. Rio de Janeiro: Elsevier, 2008, p. 283-319. 
SARLET, Ingo Wolfgang; MARINONI, Luiz Guilherme; MITIDIERO, Daniel. Curso de direito constitucional. 2. ed. São Paulo: Revista dos Tribunais, 2013.

SARMENTO, Daniel. Livres e iguais. Estudos de Direito Constitucional. Rio de Janeiro: Lumen Juris, 2006.

SILVA, Rosane Leal da et al . Discursos de ódio em redes sociais: jurisprudência brasileira. Rev. direito GV, São Paulo, v. 7, n. 2, Dec. 2011. p.445-468. Disponível em:

<http: / /www.scielo.br/scielo.php?script=sci_arttext\&pid=S1808-4322011000200004\&lng=en\&nrm =iso>. Acesso em: 05 maio 2014.

STROPPA, Tatiana. As dimensões constitucionais do direito de informação e o exercício da liberdade de informação jornalística. Belo Horizonte: Fórum, 2010.

Recebido em: 09/10/2015 / Revisões requeridas em: 23/10/2015 / Aprovado em: 11/11/2015 